\title{
Investigation of mad honey use as an alternative treatment in patients admitted to the pulmonary clinic: Ordu, Turkey example
}

\author{
Hacer Gok Ugur ${ }^{1 *}$ \\ https://orcid.org/0000-0002-0371-0556
}

Recep Sıralı ${ }^{2}$

https://orcid.org/0000-0001-9702-6175

Ahmet Talha Tekgul ${ }^{1}$

https://orcid.org/0000-0003-2990-8285

\section{Burcin Efe ${ }^{1}$}

https://orcid.org/0000-0002-3047-689X

${ }^{1}$ Ordu University Health Faculty, Department of Public Health Nursing, 52200, Ordu, Turkey; ${ }^{2}$ Namik Kemal University Veterinary Faculty, Department of Zootechnics and Animal Nutrition, 59100, Tekirdağ, Turkey.

Received: 2018.09.10; Accepted: 2019.07.08.

*Correspondence: hacer32@gmail.com; Tel.: +90-452-2265200/6432 (H.G.U.)

\section{HIGHLIGHTS}

- Patients believe that mad honey is beneficial for their health.

- Patients consume mad honey.

- Patients use mad honey for asthma, gastrointestinal diseases, hypertension, and cough.

- Age, gender, and family structure of patients affect their use of mad honey.

Abstract: This study assessed mad honey use in alternative treatments. The universe of this descriptive study was patients admitted to the pulmonary disease clinic located in the Ordu province of the Black Sea region between 15 December 2014 and 15 February 2015. We did not use a sampling method and patients who agreed to participate were included in the study $(n=353)$. In order to collect the data, we used a questionnaire prepared by the researchers. In this study, $77 \%$ of the participants stated that mad honey was beneficial to health, $44.5 \%$ used mad honey, and $53.5 \%$ consumed it daily. Furthermore, $28.7 \%$ used mad honey for asthma, $6.4 \%$ for cough, $12.1 \%$ for gastrointestinal diseases, and $3.2 \%$ for hypertension. There was a significant relationship between the gender, family structure, age, and chronic disease status of participants and the status of consuming mad honey $(p<0.05)$. In this study, participants used mad honey for asthma, gastrointestinal diseases, 
hypertension, and cough. Health professionals should provide training and counseling on the health effects and risks of mad honey to improve public health.

Keywords: Mad honey; health; alternative treatment; toxin; poisoning.

\section{INTRODUCTION}

Mad honey is extracted from the pollen and nectar of Rhododendron luteum and Rhododendron ponticum. Mad honey is produced in Nepal, Brazil, and Japan and in the eastern part of the Black Sea region of Turkey [1-3]. In Turkey, mad honey is produced by beekeepers and sold in local markets and bazaars for use in alternative treatments [4-7]. Mad honey is used as an alternative treatment for gastrointestinal disorders, hypertension, diabetes, arthritis, coronary heart disease, colds, various viral infections, and mouth sores [1, $4,5,7-11]$.

Alternative treatment is the health care systems, products, and applications not part of conventional medicine, which generally has insufficient scientific data regarding its efficacy [12]. Mad honey, which is frequently used in alternative treatments, contains a toxin called grayanotoxin [1, 2]. Grayanotoxin directly affects the heart and can lead to sudden death due to hypotension [13]. There are various poisoning cases and even sudden death reported due to mad honey consumption $[14,15]$. The toxic dose is not clearly defined and the severity of the poisoning changes depending on the dose [16]. Poisoning is more frequently observed in individuals who consume the fresh and unprocessed honey [17].

Because the content of the grayanotoxin is not clearly known, mad honey should not be used in alternative treatments [10]. The descriptive and comprehensive studies that assess mad honey use in alternative treatments are insufficient. Therefore, it is important to determine the purposes of its use for the health of society. There are a limited number of studies in the literature assessing the alternative treatment areas of mad honey. This study was performed to determine the use of mad honey in alternative treatments.

\section{MATERIAL AND METHODS}

This descriptive study was performed in the Ordu province in the eastern part of the Black Sea region of Turkey. Mad honey is mostly produced in this province in Turkey. The study was conducted with patients admitted to the pulmonary disease clinic because mad honey is particularly used for respiratory system diseases in the Ordu province. The universe of the descriptive study was patients admitted to the pulmonary disease clinic of the hospital located in the Ordu province in the Black Sea region between 15 December 2014 and 15 February 2015. We did not use any sampling method and participants who agreed to participate were included in the study ( $n=353)$. Ethically, written consent was obtained and written and verbal informed consent was obtained from the patients participating in the study. Data were collected using the face to face interview technique. In order to collect the data, we used a questionnaire prepared by the researchers in consultation with the literature $[1,5$, $7,12,18]$. The questionnaire included 17 questions related to the descriptive features of participants (age, gender, marital status, educational status, family structure, place lived the longest, income status, and the presence and type of chronic disease) and the characteristics of individuals associated with the consumption of mad honey (mad honey is beneficial for health, using mad honey, purpose of using mad honey, frequency of mad honey use, amount of mad honey in each use, experience of poisoning with mad honey, signs of mad honey poisoning, and action when poisoned with mad honey). SPSS 20.0 (Statistical Package for Social Sciences) software was used for data analysis. The statistical significance was accepted when the $p$ value was lower than $0.05(p<0.05)$. Data were shown as number, percentage distribution, and arithmetic mean. Statistical analyses were performed using the Student's t- and chi-square tests. 


\section{RESULTS}

The mean age of participants was $57.05 \pm 14.75$. Of all participants, $51 \%$ were male, $39.4 \%$ graduated from primary school, and $64.6 \%$ had a moderate income level. In addition, $62 \%$ of the patients had a chronic disease and $25.1 \%$ were asthma patients (Table 1 ).

Table 1. Descriptive characteristics of patients included in the study

\begin{tabular}{|c|c|c|c|}
\hline Descriptive characteristics & & $\mathbf{N}$ & $\%$ \\
\hline Mean age & \multicolumn{3}{|c|}{$57.05 \pm 14.75$ (Min: 30; Max: 87) } \\
\hline \multirow[t]{2}{*}{ Gender } & Female & 173 & 49.0 \\
\hline & Male & 180 & 51.0 \\
\hline \multirow[t]{2}{*}{ Marital Status } & Married & 322 & 91.2 \\
\hline & Single & 31 & 8.8 \\
\hline \multirow[t]{5}{*}{ Educational Status } & Literate & 126 & 35.7 \\
\hline & Primary school & 139 & 39.4 \\
\hline & Secondary school & 33 & 9.3 \\
\hline & High school & 31 & 8.8 \\
\hline & University & 24 & 6.8 \\
\hline \multirow[t]{3}{*}{ Family Structure } & Nuclear family & 243 & 68.8 \\
\hline & Extended family & 103 & 29.2 \\
\hline & Broken family & 7 & 2.0 \\
\hline \multirow[t]{4}{*}{ Place lived the longest } & Village & 92 & 26.1 \\
\hline & Town & 17 & 4.8 \\
\hline & District & 97 & 27.5 \\
\hline & Province & 147 & 41.6 \\
\hline \multirow[t]{3}{*}{ Income Status } & Low & 116 & 32.9 \\
\hline & Moderate & 228 & 64.6 \\
\hline & High & 9 & 2.5 \\
\hline \multirow[t]{2}{*}{ Presence of chronic disease } & Yes & 219 & 62.0 \\
\hline & No & 134 & 38.0 \\
\hline Type of chronic disease & Hypertension & 49 & 22.4 \\
\hline \multirow[t]{5}{*}{$(n=219)$} & Diabetes & 31 & 14.2 \\
\hline & Asthma & 55 & 25.1 \\
\hline & Chronic heart failure & 11 & 5.0 \\
\hline & Hypertension and Diabetes & 43 & 19.6 \\
\hline & $\begin{array}{l}\text { Hypertension, Diabetes, and } \\
\text { Asthma }\end{array}$ & 30 & 13.7 \\
\hline
\end{tabular}


In our study, $77.1 \%$ of the patients believed that mad honey was beneficial for health. Furthermore, $44.5 \%$ consumed mad honey and $28.7 \%$ used it as asthma treatment. Of all patients, $22.9 \%$ had a poisoning experience with mad honey, $33.3 \%$ had dizziness, and $16.7 \%$ were admitted to the hospital when they were poisoned after consuming mad honey (Table 2).

Table 2. Features of patients who used mad honey

\begin{tabular}{|c|c|c|c|}
\hline Habits of mad honey use & & $\mathbf{N}$ & $\%$ \\
\hline \multirow{2}{*}{$\begin{array}{l}\text { Thinking mad honey is beneficial } \\
\text { for health }\end{array}$} & Yes & 272 & 77.1 \\
\hline & No & 81 & 22.9 \\
\hline \multirow[t]{2}{*}{ Status of using mad honey } & Yes & 157 & 44.5 \\
\hline & No & 196 & 55.5 \\
\hline \multirow{5}{*}{$\begin{array}{l}\text { Purpose of using mad honey } \\
(\mathrm{n}=157)\end{array}$} & Gastrointestinal disorders & 19 & 12.1 \\
\hline & Hypertension & 5 & 3.2 \\
\hline & Asthma & 45 & 28.7 \\
\hline & Cough & 10 & 6.4 \\
\hline & Nutritional purposes & 78 & 49.7 \\
\hline \multirow{4}{*}{$\begin{array}{l}\text { Frequency of mad honey use } \\
(\mathrm{n}=157)\end{array}$} & Daily & 84 & 53.5 \\
\hline & Once a week & 26 & 16.6 \\
\hline & Once a month & 15 & 9.6 \\
\hline & Once a year & 32 & 20.4 \\
\hline \multirow{3}{*}{$\begin{array}{l}\text { Amount of mad honey per use } \\
(n=157)\end{array}$} & One teaspoon $(3 \mathrm{~g})$ & 57 & 36.3 \\
\hline & One dessert spoon ( $5 \mathrm{~g}$ ) & 54 & 34.4 \\
\hline & One tablespoon $(10 \mathrm{~g})$ & 46 & 29.3 \\
\hline \multirow{2}{*}{$\begin{array}{l}\text { Experience of poisoning with mad } \\
\text { honey }(n=157)\end{array}$} & Yes & 36 & 22.9 \\
\hline & No & 121 & 77.1 \\
\hline \multirow{6}{*}{$\begin{array}{l}\text { Signs of mad honey poisoning } \\
(n=36)\end{array}$} & Nausea and vomiting & 8 & 22.2 \\
\hline & Dizziness & 12 & 33.3 \\
\hline & Weakness & 5 & 13.9 \\
\hline & Fainting & 3 & 8.3 \\
\hline & Blackouts & 5 & 13.9 \\
\hline & Nausea, vomiting, and dizziness & 3 & 8.3 \\
\hline \multirow{3}{*}{$\begin{array}{l}\text { Action when poisoned with mad } \\
\text { honey }(n=36)\end{array}$} & I visited a doctor & 6 & 16.7 \\
\hline & I waited at home for symptom relief & 18 & 50.0 \\
\hline & I drank buttermilk & 12 & 33.3 \\
\hline
\end{tabular}


According to our findings, there was a significant relationship between the age, gender, and the family structure of patients and their status of using mad honey. Furthermore, younger patients consumed more mad honey than older patients did $(p<0.05)$ (Table 3$)$.

Table 3. Comparison of the descriptive features of patients and their status of using mad honey

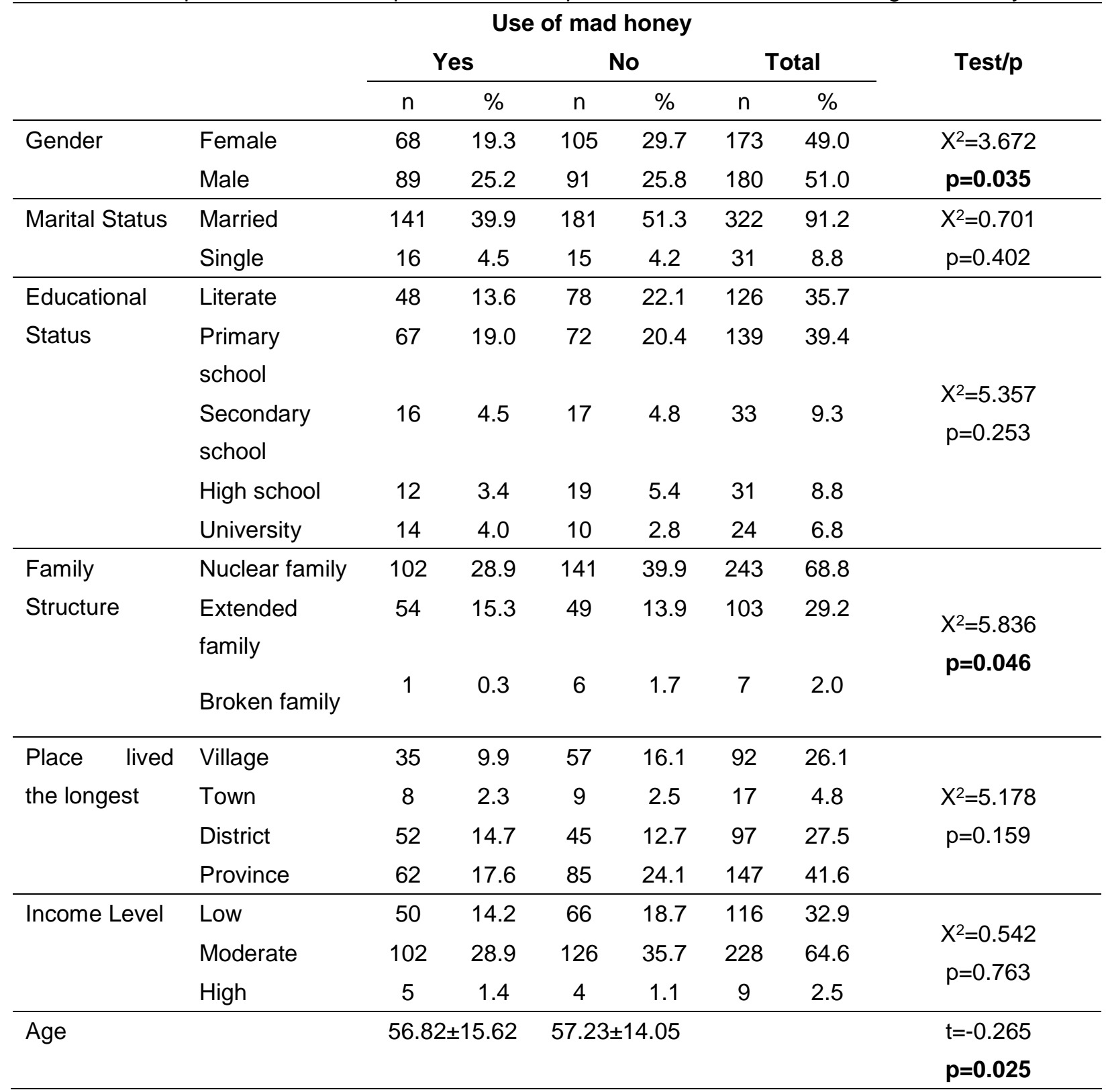

$p<0.05 ; X^{2}=$ Chi-square test; $\mathrm{t}=$ Independent Sample $t$ Test. 
In our study, there was a significant association between the chronic disease type and the status of using mad honey $(p<0.05)$ (Table 4).

Table 4. Comparison of chronic disease status with the use of mad honey

\begin{tabular}{|c|c|c|c|c|c|c|c|c|}
\hline & & \multicolumn{6}{|c|}{ The status of using mad honey } & \multirow{3}{*}{ Test/p } \\
\hline & & \multicolumn{2}{|c|}{ Yes } & \multicolumn{2}{|c|}{ No } & \multicolumn{2}{|c|}{ Total } & \\
\hline & & $\mathrm{n}$ & $\%$ & $\mathrm{n}$ & $\%$ & $\mathrm{n}$ & $\%$ & \\
\hline \multirow{2}{*}{$\begin{array}{l}\text { Presence } \\
\text { of chronic } \\
\text { disease }\end{array}$} & Yes & 96 & 27.2 & 123 & 34.8 & 219 & 62.0 & \multirow{2}{*}{$\begin{array}{c}X^{2}=0.096 \\
p=0.757\end{array}$} \\
\hline & No & 61 & 17.3 & 73 & 20.7 & 134 & 38.0 & \\
\hline \multirow{6}{*}{$\begin{array}{l}\text { Type of } \\
\text { chronic } \\
\text { disease }\end{array}$} & Hypertension & 18 & 8.2 & 31 & 14.2 & 49 & 22.4 & \multirow{6}{*}{$\begin{array}{c}X^{2}=20.026 \\
p=0.001\end{array}$} \\
\hline & Diabetes & 6 & 2.7 & 25 & 11.4 & 31 & 14.2 & \\
\hline & Asthma & 30 & 13.7 & 25 & 11.4 & 55 & 25.1 & \\
\hline & $\begin{array}{l}\text { Chronic heart } \\
\text { failure }\end{array}$ & 4 & 1.8 & 7 & 3.2 & 11 & 5.0 & \\
\hline & $\begin{array}{l}\text { Hypertension } \\
\text { and Diabetes }\end{array}$ & 17 & 7.8 & 26 & 11.9 & 43 & 19.6 & \\
\hline & $\begin{array}{l}\text { Hypertension, } \\
\text { Diabetes, and } \\
\text { Asthma }\end{array}$ & 21 & 9.6 & 9 & 4.1 & 30 & 13.7 & \\
\hline
\end{tabular}

$X^{2}=$ Chi-square test .

\section{DISCUSSION}

This study assessed the use of mad honey as an alternative treatment. In the study, $71 \%$ of the patients believed that mad honey was beneficial for health and consequently used more mad honey compared to others. Similarly, according to the study of Sagkal et al. [18], $71.2 \%$ of older individuals used herbal therapies based on their belief that these therapies were beneficial in addition to conventional medical treatments. In the study of Kav et al. [19], the majority of cancer patients specified that they believed in the benefit of complementary alternative treatment methods. This study assessed mad honey, which is traditionally used in Ordu as an alternative treatment for various diseases.

According to our results, $12.1 \%$ of the patients specified they were using mad honey for the alternative treatment of gastrointestinal diseases. Similarly, others show that mad honey is commonly used as an alternative medicine for gastrointestinal system disorders such as stomach aches, intestinal disorders, abdominal pain, indigestion, peptic ulcers, and gastritis $[4-11,16,20,21]$. In the current study, $3.2 \%$ of the patients used mad honey for hypertension. Similar to our findings, mad honey is frequently used for hypertension [1, 7-11, 16]. On the other hand, some patients used mad honey for cough. Aliyev et al. [8] and Harissis and Mavrofridis [10] showed that mad honey was beneficial as an alternative treatment for flu and colds. Furthermore, asthma was also treated with mad honey by $28.7 \%$ of our patients. These results might have been affected by the conditions of the study.

In our study, $22.9 \%$ of the patients were poisoned due to mad honey consumption. In some cases, only one teaspoon of mad honey was sufficient to poison an individual $[5,16$, 20]. Gunduz et al. [22] stated that patients were poisoned with one tablespoon of mad honey. Sogut et al. [21] reported that 2-3 tablespoons of mad honey were toxic for other patients. As the amount of consumed mad honey increases, the signs of poisoning also increase [20]. Signs of mad honey poisoning depend on the dose of mad honey, the individual, and conditions [23]. Patients experienced different signs such as nausea, vomiting, dizziness, weakness, fainting, and blackouts. The most common signs of mad honey poisoning are nausea, vomiting, sweating, dizziness, weakness, fainting, blurred vision, and low blood pressure $[5,7]$. Our findings are compatible with results of other studies. 
In our study, $50.0 \%$ of patients poisoned from mad honey consumption stated that they waited at home for the relief of symptoms. Similarly, Yucel Cavus et al. [24] reported that patients had some complaints due to mad honey consumption and waited at home for relief. Symptoms of poisoning due to mad honey are relieved within 12-24 hours in some cases [14, 25]. This short duration might be why patients waited at home for the relief of symptoms. For instance, $33.3 \%$ of the patients who were poisoned drank buttermilk. In mad honey poisoning, drinking salty buttermilk is a traditional treatment [3]. Similarly, Harissis and Mavrofridis [10] also stated that salty buttermilk is beneficial in mad honey poisoning. In our study, $16.7 \%$ of the patients were admitted to the hospital due to the poisoning. Most likely, patients who had more than one symptom or had a severe experience of poisoning were admitted to the hospital.

\section{CONCLUSION}

In this study, most of the patients thought mad honey was useful for health and used mad honey. Patients used mad honey for asthma, gastrointestinal disorders, hypertension, and cough and asthma patients consumed mad honey the most. Some of the patients who consumed mad honey did so daily and some were poisoned from mad honey. In line with these results, it is recommended that health professionals provide training and counseling on the effects and risks of mad honey in the body.

Conflict of Interest: There is no financial, personal, or academic conflict of interest.

\section{REFERENCES}

1. Oztasan N, Songur A. The use of "mad honey" as an antihypertensive agent in rats- A preliminary study. The Medical Journal of Kocatepe. 2007;8:55-8.

2. Gündüz A, Türedi S. The location of mad honey production. Turk J Emerg Med. 2009;9(2):96-8.

3. Gok Ugur H, Sıralı R, Aktürk S. Traditional treatment methods used in andromedotoxin poisoning. Journal of Apiculture Research. 2015;7(13):34-5.

4. Dilber E, Kalyoncu M, Yaris N, Okten A. A case of mad honey poisoning presenting with convulsion: intoxication instead of alternative therapy. Turk J Med Sci. 2002;32:361-2.

5. Gunduz A, Turedi S, Russell RM, Ayaz FA. Clinical review of grayanotoxin/mad honey poisoning past and present. Clin Toxicol. 2008;46(5):437-42.

6. Demircan A, Keleş A, Bildik F, Aygencel G, Doğan NO, Gómez HF. Mad honey sex: therapeutic misadventures from an ancient biological weapon. Ann Emerg Med. 2009;54:824-9.

7. Demir H, Denizbası A, Onur O. Mad honey intoxication: A case series of 21 patients. ISRN Toxicology. Volume 2011; 2011: 526426. doi:10.5402/2011/526426.

8. Aliyev F, Türkoglu C, Celiker C, Fıratı I, Alıcı G, Uzunhasan I. Chronic mad honey intoxication syndrome: A new form of an old disease? EP Europace. 2009;11(7):954-6. doi:10.1093/europace/eup126.

9. Yaylacı S, Ösken A, Olt S, Temiz T, Tamer A, Gündüz H. Mad honey poisoning accompanied by hypotension and bradycardia. Sakarya Medical Journal. 2011;1(2):73-5.

10. Harissis HV, Mavrofridis G. "Mad honey" in medicine from antiquity to the present day. Arch latr Hetaireon. 2013;30(6):730-3.

11. Vardar A. Mad Honey poisoning [Internet]. [place unknown: publisher unknown]; [cited 2015 Dec 10]. Available from: http://file.atuder.org.tr/atuder.org/fileUpload/clt6VbhqDizM.pdf.

12. Özçelik H, Fadıloğlu Ç. Reasons for use of complementary and alternative medicine in cancer patients. Türk Onkoloji Dergisi. 2009;24(1):48-52.

13. Şahin H, Kolaylı S. Miraculous cure including a mysterious weapon. Oray-Bir'in Sesi. 2012;7(8):20-1.

14. Başgül A. Mad honey intoxication. Turkish Journal of Intensive Care Medicine. 2003;3(1):33-6.

15. Hancı V, Bilir S, Kırtaç N, Akkız S, Yurtlu S, Özkoçak Turan I. Mad honey poisoning in Zolguldak region: analyses of seventy-two cases. Turk J Anaesthesiol Reanim. 2010;38(4):278-84.

16. Ozhan H, Akdemir R, Yazici M, Gündüz H, Duran S, Uyan C. Cardiac emergencies caused by honey ingestion: a single centre experience. Emerg Med J. 2004;21(6):742-4.

17. Koçak S, Uçar K, Gül M. Mad honey poisoning. Genel Tıp Dergisi. 2008;18(3):137-8.

18. Sagkal $T$, Demiral $S$, Odabaş $H$, Altunok E. Complementary and alternative treatment methods among elderly individuals in living rural setting. Firat University Medical Journal of Health Sciences. 2013;27(1):19-26. 
19. Kav S, Hanoğlu Z, Algıer L. Use of complementary and alternative medicine by cancer patients in Turkey: A literature review. THOD-The Turkish Journal of Hematology and Oncology. 2008;18(1):32-38.

20. Sütlüpınar N, Mat A, Satganoğlu Y. Poisoning by toxic honey in Turkey. Arch Toxicol. 1993;67:148-50.

21. Sogut O, Sayhan MB, Mordeniz C, Gokdemir MT, Al B. Mad honey poisoning: a case report and review of the literature. Anatol J Clin Investig. 2009;3(1):100-2.

22. Gunduz A, Merice ES, Baydin A, Topbas M, Uzun H, Turedi S, Kalkan A. Does mad honey poisoning require hospital admission? Am J Emerg Med. 2009;27:424-7.

23. Choi YS, Jang IS. A case of severe bradyarrhythmia after ingestion of rhododendron bradycarpum. Korean Circulation J. 2002;32:268-70.

24. Yucel Çavus U, Işık B, Tekin O. Mad-honey poising. The New Journal of Medicine. 2010;27:187-9.

25. Ergun K, Tufekcioglu O, Aras D, Korkmaz S, Pehlivan S. A rare cause of atrioventricular block: Mad honey intoxication. Int J Cardiol. 2005;99:347-8. 